\title{
Soviet catches of right whales Eubalaena japonica and bowhead whales Balaena mysticetus in the North Pacific Ocean and the Okhotsk Sea
}

\author{
Yulia V. Ivashchenko ${ }^{1,2, *}$, Phillip J. Clapham ${ }^{1}$ \\ ${ }^{1}$ National Marine Mammal Laboratory, Alaska Fisheries Science Center, Seattle, Washington 98115, USA \\ ${ }^{2}$ School of Environmental Science and Management, Southern Cross University, Lismore, New South Wales 2480, Australia
}

\begin{abstract}
Both bowhead Balaena mysticetus and North Pacific (NP) right whales Eubalaena japonica were reduced to low levels by historical whaling. Despite their protected status, it is known that the USSR illegally killed both species in the NP and Okhotsk Sea (OS). Here, we provide revised Soviet catch totals, as well as other new information on the distribution and other details of these catches. Right whale catches were made from 1962 to 1968 in the eastern NP and in 1967 and 1968 in the OS. Our best estimate of total right whale catches is 661, consisting of 529 for the eastern NP (compared to the previously published figure of 372) and 152 for the OS (cf. a previous figure of 136). Catches were distributed in the Bering Sea (BS, 115), eastern Aleutian Islands (28), Gulf of Alaska (GOA, 366), OS (132), and other areas (20). Detailed information on catches of 112 right whales taken in May/June 1963 shows a broad distribution in offshore waters of the GOA, consistent with 19th century historical whaling records. Other major areas in which right whales were caught include south of Kodiak Island, western Bristol Bay (southeastern BS), and the central OS off eastern Sakhalin Island. The best estimate of bowhead whale catches in the OS in 1967 and 1968 is 145 animals, although this is contingent upon certain assumptions regarding species identity. Of these, 79 were killed in the Shantar Islands region and 66 in Shelikhov Bay. The catches of both species primarily involved large mature animals, thus greatly inhibiting recovery of the populations concerned.
\end{abstract}

KEY WORDS: Whaling $\cdot$ Illegal whaling $\cdot$ USSR $\cdot$ Distribution $\cdot$ Life history

\section{INTRODUCTION}

Both the North Pacific right whale Eubalaena japonica and the bowhead whale Balaena mysticetus were subject to intensive hunting by commercial whalers beginning in the 19th century. Currently, North Pacific right whales are considered to exist in 2 discrete populations: eastern and western (Brownell et al. 2001). There are also 2 recognized populations of bowhead whales in this region: the BeringChukchi-Beaufort (BCB, also known as the western Arctic) and Okhotsk Sea (OS) stocks (Burns et al.
1993). With the exception of the BCB population, the right and bowhead whale stocks are believed to be at low abundance, and limited information is available with regard to status, distribution, and historical population size (Clapham et al. 1999).

The range of eastern North Pacific right whales is believed to encompass the Gulf of Alaska (GOA) and the Bering Sea (BS), while the western population inhabits the northwestern Pacific and the OS. Recently, genetic and photo-ID mark-recapture data were used to generate independent estimates of abundance for the eastern population; both estimates indicated that 
only $~ 30$ animals remain (Wade et al. 2011). Although this may represent a sub-population that inhabits the BS in summer, and could therefore under-represent total abundance, the recent paucity of sightings strongly suggests that the overall eastern population is not much larger; thus, this is the smallest large whale population in the world for which an abundance estimate exists. The only existing estimate of the western North Pacific right whale population comes from 3 Japanese minke whale Balaenoptera acutorostrata sighting surveys in the OS conducted between 1989 and 1992 (Miyashita \& Kato 1998). This estimate was 922 animals (CV = 0.433, CI: 404-2108); however, both positive and negative potential biases were identified in the survey methodology, and the estimate must be considered of questionable reliability given its low precision (Best et al. 2001).

Bowhead whales in the OS constitute a genetically and geographically distinct population (Rugh et al. 2003, LeDuc et al. 2005, Ivashchenko \& Clapham 2010) which is currently listed as Endangered by the International Union for Conservation of Nature (Reilly et al. 2008). Information about OS bowheads was recently summarized by Ivashchenko \& Clapham (2010), who highlighted a lack of knowledge about current population size, habitat use, and seasonal movements.

The precarious status of these 3 remnant balaenid populations is the consequence of extensive and unregulated whaling that began in the mid-19th century and drove the populations to commercial extinction in just a few decades (Scarff 1991, Bockstoce \& Burns 1993, Clapham et al. 1999). Hunting for right whales began in the GOA in 1835 and spread to the OS a decade later. The number of right whales killed in the eastern North Pacific in the 19th century was estimated by Scarff (2001) at 26000 to 37000 animals, and it is still unclear how many right whales were killed in the western population. Limited catches continued into the 20th century; in 1935, all right whales were (in theory if not practice) protected by international agreement. Brownell et al. (2001) summarized all known information on 20th century commercial and scientific catches at the time of their review, and reported 411 and 331 right whales taken from the eastern and western North Pacific, respectively, between 1900 and 1977 .

Bowhead whales in the OS were first hunted in about 1847, and this population is believed to have been greatly reduced from its pre-whaling size; however, how large this was remains the subject of considerable debate, and all estimates are confounded by incomplete and sometimes equivocal historical data (see discussion in Ivashchenko \& Clapham 2010). Mitchell (1977) estimated the pre-whaling population at 6600 whales, a figure which Woodby \& Botkin (1993) considered too high. In contrast, D. A. Henderson (unpublished, reported by Kugler 1984) suggested that more than 15000 bowheads had been taken in the first $20 \mathrm{yr}$ of the fishery.

In addition to the 19th and 20th century catches, it is now known that Soviet whaling fleets operating in the North Pacific killed both right and bowhead whales as part of a global campaign of illegal whaling that began in 1948 (Ivashchenko et al. 2008, 2011, Clapham \& Ivashchenko 2009). Note that 'illegal' here means contrary to the International Convention for the Regulation of Whaling 1946, to which the USSR was a signatory; the Convention and its accompanying Schedule included provisions completely protecting right and bowhead whales. While catches for the purpose of scientific research were permitted under Article VIII of the Convention, any country issuing its nationals a permit for such catches was required to report them to the International Whaling Commission (IWC). All commercial catches of these 2 species were banned.

Soviet factory fleets killed many right whales from 1962 until 1968, primarily in the GOA and the southeastern BS. In addition, both right and bowhead whales were killed illegally in the OS in 1967 and 1968. A few years after Yablokov (1995) published the first information on the true extent of whale catches by Soviet factory fleets, former Soviet biologist Nikolay Doroshenko (2000a) published a paper which provided some information about right and bowhead whale catches in the North Pacific during the period 1963 to 1968. However, he provided few details regarding the positions or timing of these catches, and his assessment is known to have been based upon incomplete information.

A recent search of local archives in Russia has revealed numerous Soviet whaling industry reports, some of which were not available to Doroshenko or others seeking to reconstruct the true Soviet catch history for the North Pacific region. Here, using these previously unexamined materials, we report that catches of right whales in the eastern North Pacific during the period 1962 to 1968 were larger than previously assumed. We also provide new information on the distribution and timing of right whale occurrence in the GOA and BS, as well as previously unavailable details of right and bowhead whale catches in the OS in 1967 and 1968. Finally, we present significant new biological information from these catches (notably length distribution and maturational 
status) for North Pacific right whales, a species for which few such data have been previously available, as well as some similar data for bowheads in the OS.

\section{MATERIALS AND METHODS}

The information summarized in this paper is based upon various Russian sources, consisting of published Soviet literature about bowhead and North Pacific right whales, and formerly secret reports from Soviet whaling operations; the latter are summarized in Table 1. These formerly secret reports represent our primary source of information and include scout vessel reports, scientific reports, whaling production reports, and reports from the Soviet government's official whaling inspectors who were present aboard factory ships. These materials were previously unpublished and largely unavailable until their declassification; they were recently discovered during searches of public archives in Russia.

The range of reports is incomplete, with some types of reports missing for specific years and whaling fleets. Furthermore, the information contained in the various reports is not consistently presented: some reports have considerable detail on catches (including individual positions and dates), while others give only a gross summary of sighted or killed whales during 1 or 2 mo periods and/or over large geographic areas, with no vessel tracks shown. In other words, possession of a particular report does not necessarily mean that there is detailed information about catches for that fleet and whaling season.

In a few cases, information in whaling production reports directly contradicts catch data given in other types of reports for the same whaling fleet and year, usually by replacing right or bowhead whales with names of other species; this appears to have been an attempt — odd in view of the fact that all such reports were secret - to hide catches of protected species in the production reports. In these cases, the true catches appear in either the scientific or inspection reports for that year, and those data have been used here. In order to resolve this issue, and to clarify other details, interviews were conducted with scientists who were present on the whaling factory ships during the catches of right whales, or who were familiar with aspects of the fleets' operations. Details of the interviewees, and an overview of Soviet illegal whaling in general, were given by Ivashchenko et al. (2011).

Maps for right and bowhead whale catches and sightings were created using ArcView geographical information system software (ESRI1). This involved recreating maps from reports by scanning figures and saving the resulting images as JPEG files. These files were imported into ArcMap as a raster data set layer and saved as a georeferenced map.

\section{RESULTS}

\section{North Pacific right whales}

Four whaling factory fleets were involved in North Pacific right whale catches at various times: 'Sovetskaya Rossiya,' 'Aleut,' 'Vladivostok,' and 'Dalniy Vostok.' The factory ship 'Slava' also operated in the North Pacific in the summers of 1966 to 1969, but is not known to have killed either right or bowhead whales. The first Soviet whaling expedition to the eastern North Pacific (east of $180^{\circ}$ ) occurred in 1960, when the 'Aleut' began whaling operations along the eastern Aleutian Islands. Rovnin (1969) described intensive survey coverage by scout and research vessels in the eastern North Pacific beginning in 1958, which preceded the expansion of the Soviet whaling effort to the east; he stated that 18 scientific/scout vessel surveys were completed in the North Pacific between 1958 and 1968. Although 'Aleut' was the

Table 1. List of available reports for Soviet whaling fleets that worked in the North Pacific. SR: scientific report; WR: whaling production report; Other: statistical reports and/or inspectors' reports

\begin{tabular}{|c|c|c|c|c|c|c|c|c|c|c|c|c|c|}
\hline \multirow{2}{*}{ Year } & \multicolumn{3}{|c|}{ 'Sovetskaya Rossiya' } & \multicolumn{3}{|c|}{ 'Aleut' } & \multicolumn{3}{|c|}{ 'Vladivostok' } & \multicolumn{3}{|c|}{ 'Dalniy Vostok' } & \multirow{2}{*}{$\begin{array}{c}\text { Scout vessel } \\
\text { report }\end{array}$} \\
\hline & $\mathrm{SR}$ & WR & Other & SR & WR & Other & SR & WR & Other & SR & WR & Other & \\
\hline 1962 & + & + & & & & & & + & & & & & + \\
\hline 1963 & + & + & & & + & & & + & & & + & & + \\
\hline 1964 & + & & & & & + & + & & + & + & + & + & + \\
\hline 1965 & + & & & & & & & + & & & + & & + \\
\hline 1966 & & + & & & & & & + & & & + & + & \\
\hline 1967 & & + & & & & & + & + & & + & + & + & \\
\hline 1968 & & & & & & & & & + & + & & & + \\
\hline
\end{tabular}


first Soviet whaling fleet to work in the eastern part of the North Pacific, shortly afterwards 3 larger fleets concentrated their efforts on this area: 'Sovetskaya Rossiya' beginning in 1962, and 'Vladivostok' and 'Dalniy Vostok' from 1963. Some whaling effort (primarily at the beginning and the end of each season) was still directed at the western North Pacific after 1960, but due to depleted whale resources whalers paid less attention to these areas, unless large aggregations of whales were found.

Using incomplete data, Doroshenko (2000a) reported catches of 372 and 126 right whales from the eastern and western populations, respectively. He subsequently stated (N. V. Doroshenko pers. comm.) that the 372 right whale catches were made by 2 Soviet whaling factory fleets, 'Dalniy Vostok' and 'Vladivostok.' He had no other information on these catches, nor on any additional right whale catches that might have been made by other Soviet fleets. The 126 right whales from the western stock were reported as being taken in a single location off eastern Sakhalin Island in the OS, in 1967.

We can now update this information based upon new material, which includes some reports from the 'Sovetskaya Rossiya' that do not appear to have been available to Doroshenko. Indeed, the first known illegal catches of North Pacific right whales were made in 1962 by this large factory fleet, and Soviet catches continued at various times until 1968. In Table 2, we summarize all known Soviet catches of North Pacific right whales during the period 1962 to 1968 in 3 main areas: the GOA, the southeastern BS, and the OS; this table shows the totals given by Doroshenko (2000a) as well as those calculated from the new data. Table 3 gives details of all Soviet catches and sightings for the period 1958 to 1968, with the best available data on time and location. Soviet sightings and catches of North Pacific right whales (and effort) during the period 1958 to 1968 are summarized by month and area in Table 4.

Overall, our best estimate for the number of right whales killed by Soviet whaling fleets in all areas between 1962 and 1968 is 661 animals (this revised catch total includes, i.e. is not in addition to, the whales reported by Doroshenko 2000a and Brownell et al. 2001).This estimate includes 529 in the eastern North Pacific; some uncertainty regarding the GOA component of this total is discussed below. Soviet fleets killed an additional 132 right whales in the OS in 1967 and 1968. Details of catch totals, timing, and distribution are given by area below.

\section{Analysis of records from 1964}

Table 3 lists all known catches and sightings of North Pacific right whales from 1958 to 1968, with as much information about dates and locations as is available in the reports that we analyzed. However, we note that, in the case of the catches from 1964, this information had to be deduced from a combination of details provided in a single scientific report that covered the activities of both the 'Vladivostok' and 'Dalniy Vostok' whaling fleets (Doroshenko et al. 1965). The total catch of right whales for these 2 fleets in 1964 was 178 whales. However, to find the details of each fleet's catches by month and by area required an analysis of 3 separate tables. The relevant tables in Doroshenko et al. (1965) are as follows: their Table 4 provides data on the catches by the 'Dalniy Vostok' factory fleet by area and different

Table 2. Eubalaena japonica. Catches of right whales in the eastern North Pacific as given by Doroshenko (2000a, his Table 3) and from our new data. 'Other/unknown areas' include areas along the western coast of North America south of the Gulf of Alaska, offshore areas in the Pacific Ocean, and the western Aleutian Islands. SE: southeastern

\begin{tabular}{|c|c|c|c|c|c|c|c|c|c|}
\hline \multirow[t]{2}{*}{ Year } & \multicolumn{3}{|c|}{ —Doroshenko (2000a) } & \multirow[b]{2}{*}{$\begin{array}{l}\text { Gulf of } \\
\text { Alaska }\end{array}$} & \multirow[b]{2}{*}{$\begin{array}{l}\text { SE Bering } \\
\text { Sea }\end{array}$} & \multicolumn{2}{|c|}{ - New data } & \multirow[b]{2}{*}{$\begin{array}{c}\text { Other/ } \\
\text { unknown areas }\end{array}$} & \multirow[b]{2}{*}{ Total } \\
\hline & $\begin{array}{l}\text { Gulf of } \\
\text { Alaska }\end{array}$ & $\begin{array}{l}\text { SE Bering } \\
\text { Sea }\end{array}$ & $\begin{array}{l}\text { Okhotsk } \\
\text { Sea }\end{array}$ & & & $\begin{array}{c}\text { Eastern } \\
\text { Aleutian Islands }\end{array}$ & $\begin{array}{l}\text { Okhotsk } \\
\text { Sea }\end{array}$ & & \\
\hline 1962 & & & & & & 21 & & 2 & 23 \\
\hline 1963 & 141 & & & $253^{\mathrm{a}}$ & & 7 & & 15 & 275 \\
\hline 1964 & 87 & 113 & & 87 & 113 & & & & 200 \\
\hline 1965 & 20 & & & 20 & & & & & 20 \\
\hline 1966 & 3 & & & 3 & & & & & 3 \\
\hline 1967 & & 8 & 126 & 3 & 2 & & 126 & 3 & 134 \\
\hline 1968 & & & & & & & 6 & & 6 \\
\hline Total & 251 & 121 & 126 & 366 & 115 & 28 & 132 & 20 & 661 \\
\hline
\end{tabular}




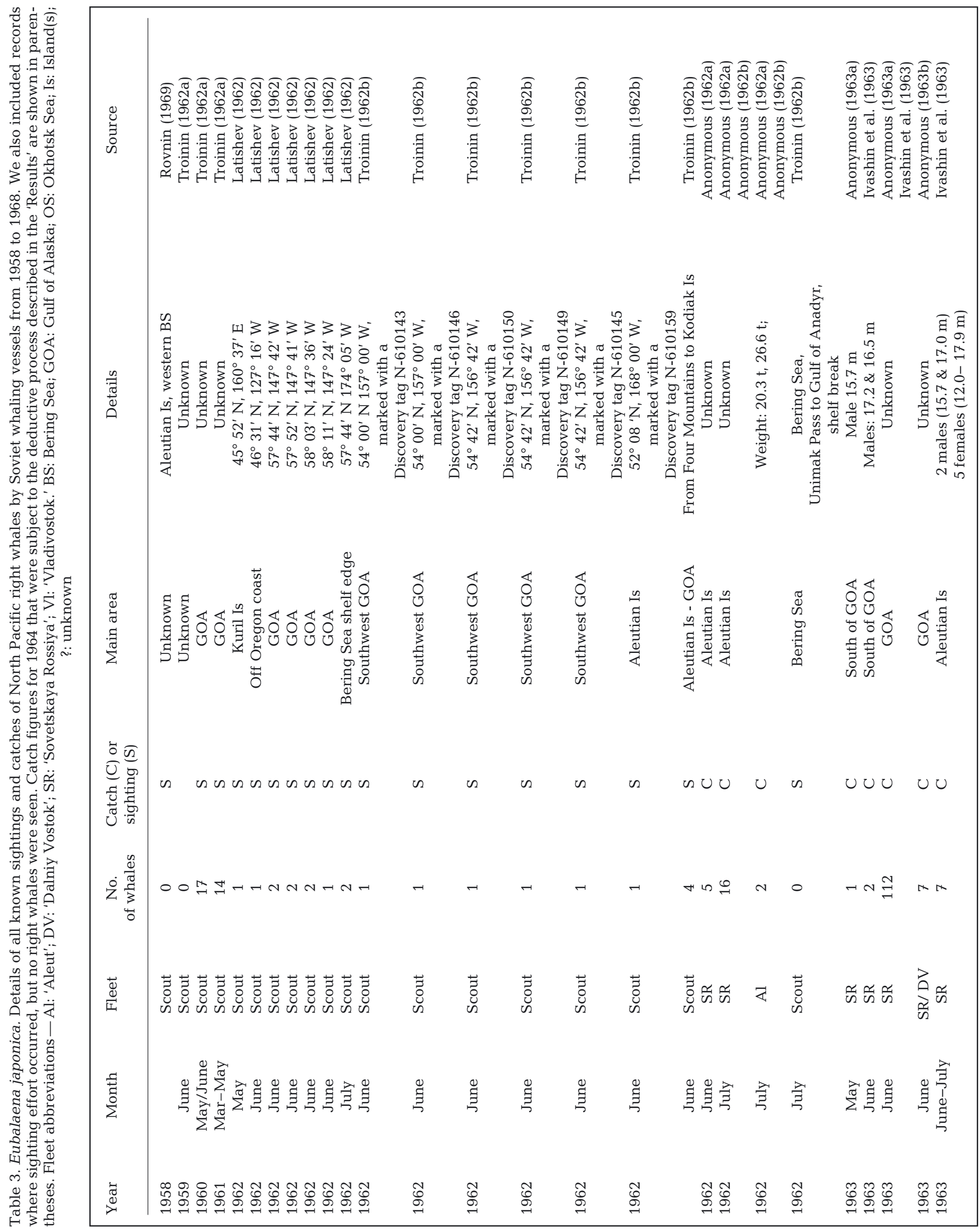



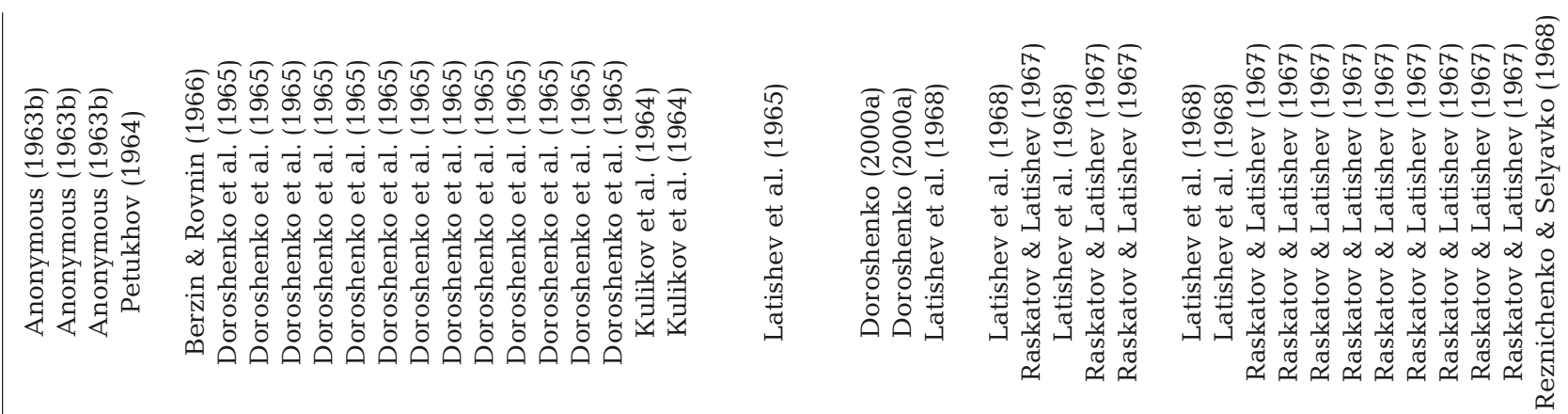

ஜี

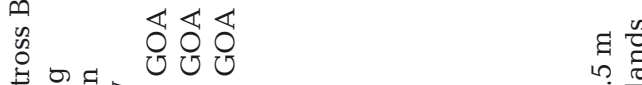

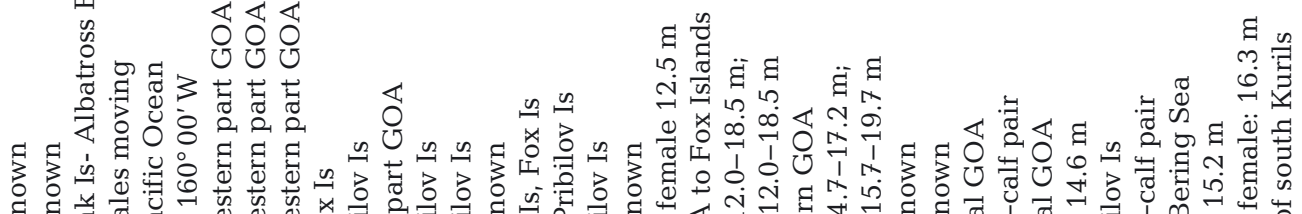

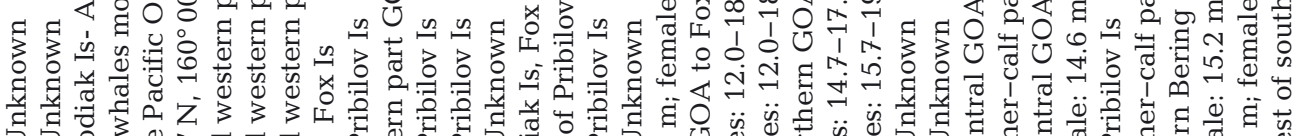

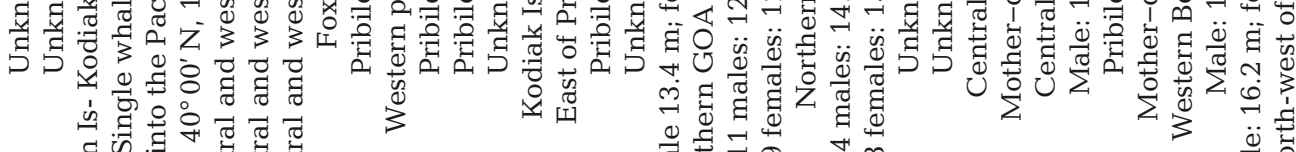

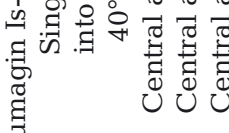

蛋

ज्ञ

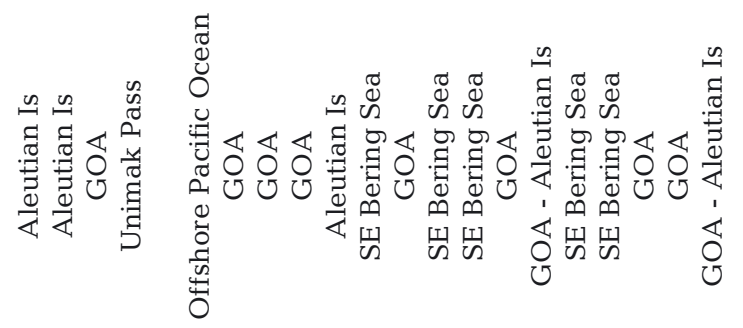

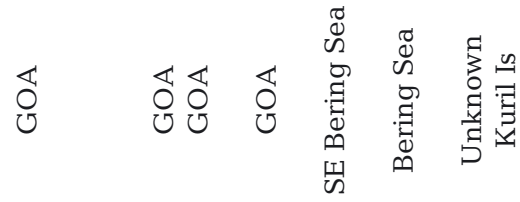

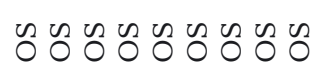

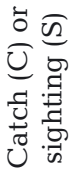

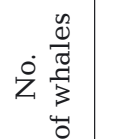

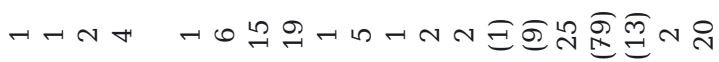

n m

$\rightarrow+h \stackrel{2}{\rightarrow}$

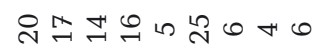

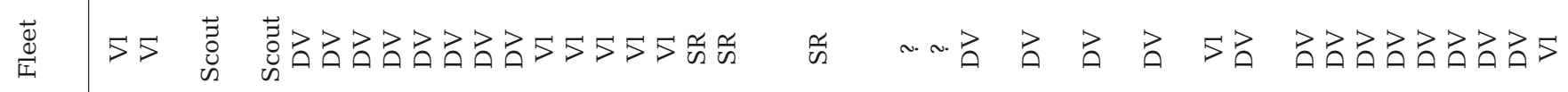

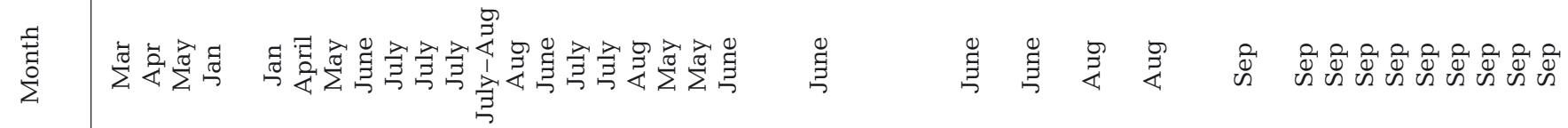

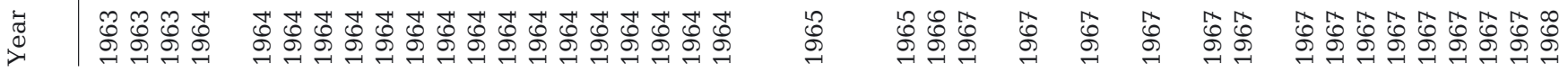


Table 4. Eubalaena japonica. Soviet sightings and catches of North Pacific right whales by month and area during the period 1959 to 1968. Effort and sightings are denoted by circles: O: survey effort but no right whales found; $\bullet$ : right whale sightings or catches. Blank cell: no known effort; ?: unknown. The major areas included in the 'Other' category, where known, include areas along the western coast of North America south of the Gulf of Alaska (GOA), offshore areas in the Pacific Ocean, and the western Aleutian Islands

\begin{tabular}{|c|c|c|c|c|c|c|c|c|c|c|c|c|}
\hline Area & Jan & Feb & Mar & Apr & May & Jun & Jul & Aug & Sep & Oct & Nov & Dec \\
\hline GOA & & & 0 & • & • & • & - & $?$ & 0 & 0 & & \\
\hline Southeast Bering Sea & & & & 0 & 0 & 0 & - & - & 0 & & & \\
\hline Eastern Aleutian Islands & - & & & 0 & 0 & - & - & 0 & 0 & 0 & & \\
\hline Other & • & 0 & - & 0 & • & 0 & 0 & 0 & 0 & 0 & 0 & \\
\hline
\end{tabular}

time periods (which range in duration from 2 to $3 \mathrm{~d}$ to $1 \mathrm{mo}$ ); Table 7 gives details of areas in which the 'Vladivostok' factory fleet worked, over periods of from 3 to $30 \mathrm{~d}$; and Table 14 presents a summary of catches by both fleets by species and month (not separated by fleet).

In order to understand the temporal and spatial distribution of each fleet's catches by month and by the 2 main areas concerned (BS and GOA), we first used Table 4 (in Doroshenko et al. 1965) to find the catches made by 'Dalniy Vostok,' and subtracted these catches from the combined total for both fleets given in their Table 14 ; the result was the total catch for 'Vladivostok.' We then used information in their Table 7 to derive the locations and/or time periods of the catches. For example, their Table 4 shows 19 right whales caught by 'Dalniy Vostok' in June in the GOA; their Table 14 indicates that the total catch for both fleets was 20, meaning that only 1 right whale was killed in June by the whaling fleet 'Vladivostok.' The next step was to find the location of the 'Vladivostok' fleet during June in order to assign this single animal to a particular area. From their Table 7 , we found that they were operating in several areas from the Queen Charlotte Islands to the western part of the GOA; consequently, the catch was assigned simply to the GOA. Next, the same process was applied to right whale catches made in August: 2 right whales were caught by the 'Dalniy Vostok' fleet, and since the total catch by both fleets for August was 82, 80 right whales must have been taken by the 'Vladivostok.' The area of work for this latter fleet in August (given in Doroshenko et al. 1965, their Table 7) was the southeastern BS.

A check on the accuracy of this analysis was provided in Table 8 of Doroshenko et al. (1965), which shows that the combined total catch for the 2 fleets had to be equal to 113 and 65 right whales in the southeastern BS and GOA, respectively.
Catch figures for 1964 that were subject to this deductive process are shown in our Table 3 in parentheses.

\section{Gulf of Alaska}

Beginning in 1960, right whales were regularly sighted by Soviet whalers and scout vessels in the GOA during the months of late spring and summer. One of the earlier surveys (Troinin 1962a), which ran from the beginning of March to the middle of May 1961, recorded 14 right whales (Table 3); unfortunately, the exact dates or even months of these sightings are not mentioned, but it is possible that some of these whales could have been seen as early as March. During subsequent surveys (Latishev 1962, Troinin 1962b, Petukhov 1964), a few whales were found in the GOA in April/May, with the majority of known sightings and catches made during June/July. It is unknown whether any of the right whale catches were made in August/September (months when Soviet whaling fleets were also operating in the area), but the survey coverage of the scout vessels was lower at that time compared to the earlier months, and their reports for this period do not include right whale sightings.

The first known Soviet catches of right whales were made in 1962 (21 in the eastern Aleutians, and 2 whales from an unknown area), with a large increase in 1963 and a rapid decline during the 1964 to 1966 seasons (Table 2). The total catch for the GOA area is probably 366 animals, although some uncertainty relating to the 1963 whaling season is discussed below.

In June 1963, the 'Sovetskaya Rossiya' whaling fleet sailed through the GOA and, according to the whaling and scientific reports (Anonymous 1963a, Ivashin et al. 1963), killed 112 right whales in the GOA and an additional 10 whales just south and west 
of this region. Doroshenko (2000a) listed 141 right whales killed in the GOA but later specified (N. V. Doroshenko pers. comm.) that for this year he had reports from only the whaling fleets 'Vladivostok' and 'Dalniy Vostok,' and did not see data from 'Sovetskaya Rossiya.' Consequently, the total catch of right whales in 1963 for all 3 Soviet fleets operating in this area should be 253 animals. However, we should note 2 issues of uncertainty relating to these numbers.

First, there is potential overlap because 3 catchers from the 'Dalniy Vostok' fleet were assigned to 'Sovetskaya Rossiya' from May through the middle of July; therefore, it is possible that as many as 17 right whales that were caught by these 3 catchers could have been double-counted in the 2 reports from 'Sovetskaya Rossiya' and 'Dalniy Vostok.' Second, although he stated (N. V. Doroshenko pers. comm.) that he did not have access to the 1963 season report from 'Sovetskaya Rossiya,' Doroshenko $(2000 a, b)$ list catches of humpback and blue whales from this fleet and year. N. V. Doroshenko (pers. comm.) does not recall where he obtained those data, so it is possible that the 'Sovetskaya Rossiya' catches were included in his stated total of 141 right whales. However, the map of catch distribution given by Doroshenko (2000a, his Fig. 1) shows catches made over an area of the GOA just south of Kodiak. He indicated (pers. comm.) that these were the whales taken by the 'Vladivostok' and 'Dalniy Vostok' fleets. In contrast, the 'Sovetskaya Rossiya' catches were distributed east and southeast of Kodiak (Fig. 1), and covered a broad area of the GOA. Accordingly, we believe that the latter catches were not included in Doroshenko's 141 for 1963 and therefore that the total GOA catch for that year was 253 whales (of which 17 may have been double-counted); unfortunately, however, this question cannot be resolved without independent review of the scientific reports for the 'Vladivostok' and 'Dalniy Vostok' fleets from 1963, which to date have not been located.

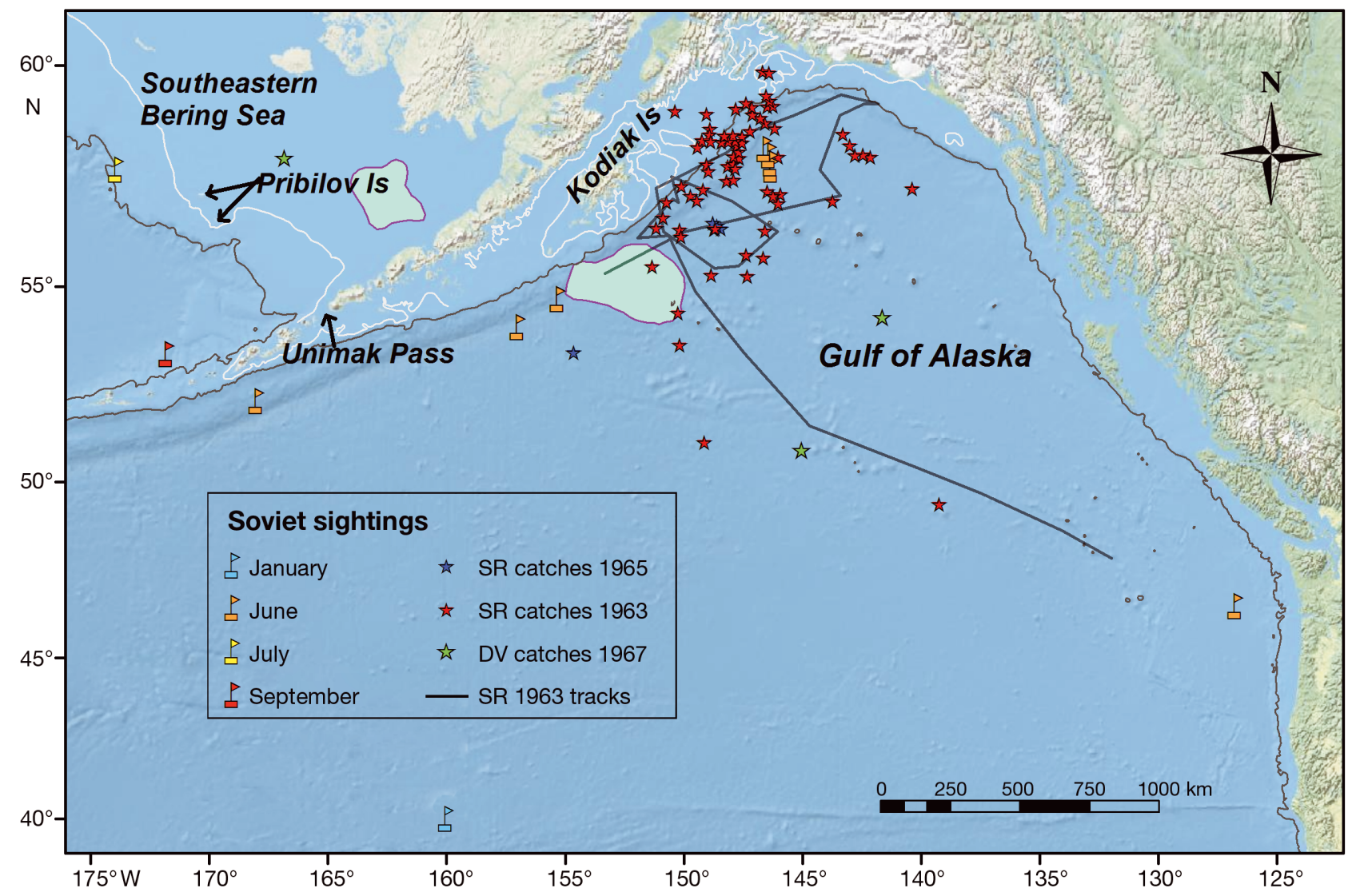

Fig. 1. Eubalaena japonica. Distribution of Soviet sightings (by month) and catches (by year) of right whales in the eastern North Pacific during the period 1958 to 1968. Pink outlined areas represent the approximate area of right whale catches as given by Doroshenko (2000a). DV: 'Dalniy Vostok' fleet; SV: 'Sovetskaya Rossiya' fleet' 
The 'Sovetskaya Rossiya' reports also provide rare data on length and maturity of North Pacific right whales; these are summarized separately below.

\section{Southeastern Bering Sea}

The southeastern BS was surveyed often but less methodically than the GOA. Except for a few right whale sightings and catches, there are no data with exact positions, and most of the information provided is limited to the total number of whales caught in a particular month. The catches of right whales did not begin in the BS until the summer of 1964, when 113 whales were killed during late July and August. There are no biological data or locations for these catches, and the only information on positions comes from Doroshenko (2000a), which shows the general catch area as a shaded block west of Bristol Bay. Doroshenko (2000a) placed catches of 8 whales for 1967 in the southeastern BS area, but our new data indicate that only 2 right whales were taken there; 3 right whales were killed in the eastern GOA, 1 was taken in the northern BS, and the locations of 2 other catches are unknown (Raskatov \& Latishev 1967 , Latishev et al. 1968). The total catch of right whales from the southeastern BS was 115 (113 in 1964 and 2 others in 1967).

\section{Eastern Aleutian Islands}

Relatively few catches and sightings were made by Soviet whalers around the eastern Aleutian Islands (from the Alaska Peninsula to $180^{\circ} \mathrm{W}$ ). The 'Sovetskaya Rossiya' whaling fleet killed 21 right whales somewhere in this area in 1962, and 7 in the following year (Anonymous 1962a, Ivashin et al. 1963). In both years, these catches were made at the end of June and in the first half of July. There is no information regarding when/if scout vessels observed right whales in the area other than from Rovnin's (1969) sightings map. This map shows just 4 observations south of the Aleutian Islands but quite a large number of sightings north of this, between Unimak Pass, Atka, and the Pribilof Islands; however, these could be Japanese sightings that were made before 1964 .

One interesting observation comes from the report of a scout vessel that was surveying different areas of the eastern North Pacific during the months of winter and spring in 1963 to 1964 (Petukhov 1964). It describes 4 sightings of single right whales moving through Unimak Pass toward the Pacific Ocean on 12
January 1964. Two of these animals were marked with Discovery tags, but it is not known whether the tags were ever recovered.

\section{Okhotsk Sea}

In 1967, the Soviet whaling fleet 'Dalniy Vostok' caught 126 North Pacific right whales in the OS, off the southeastern coast of Sakhalin Island (Doroshenko 2000a). Until now it was believed that all of these catches were made in 1 area (off Cape Terpeniya) where a large aggregation of right whales was said to have been found and wiped out in $10 \mathrm{~d}$. New details of the right whale catches in the OS in 1967 come from the inspectors' report of the whaling fleet 'Dalniy Vostok' (Raskatov \& Latishev 1967). There are no differences in the total number of right whales killed, but the map shows that these catches were not as aggregated in space as Doroshenko (2000a) had indicated. The inspectors' map is shown in Fig. 2, and gives the track of the fleet based upon the factory ship's noon position every day, as well as any catches made on that day. Overall, the catches were distributed over a large area. They began in the southern Kuril Islands, then continued off Cape Terpeniya (southeastern Sakhalin Island); further catches were then made to the north along the eastern coast of Sakhalin, then east in an area farther offshore of northeastern Sakhalin, and finally south again (Fig. 2). The daily catches ranged from 3 or 4 to 22-26 right whales, with no obvious area of concentration. In the scientific report from the 1967 season (Latishev et al. 1968), right whale catches were described as being of large, mostly mature animals (see details in the biological data section below).

The next year (1968), another Soviet whaling fleet, the 'Vladivostok,' was working in the OS in September. While on its way to the Shantars area (on the western edge of the OS, Fig. 2) the fleet caught 6 'right whales' (the Russian generic term for balaenids; see the section on bowhead whales below) on 11 September off the northern end of the eastern coast of Sakhalin Island; this location was very close to catches made on 20 September of the previous year (Fig. 2). Although all of the catches made by the 'Vladivostok' fleet after 11 September are considered to be bowhead whales (see below), we believe that the 6 whales killed on 11 September were actually North Pacific right whales. This is based upon a lack of bowhead whale sightings in this area and periodic observations of right whales offshore of the northeastern coast of Sakhalin (Miyashita \& Doroshenko 1990, Miyashita 1997, 2004). 


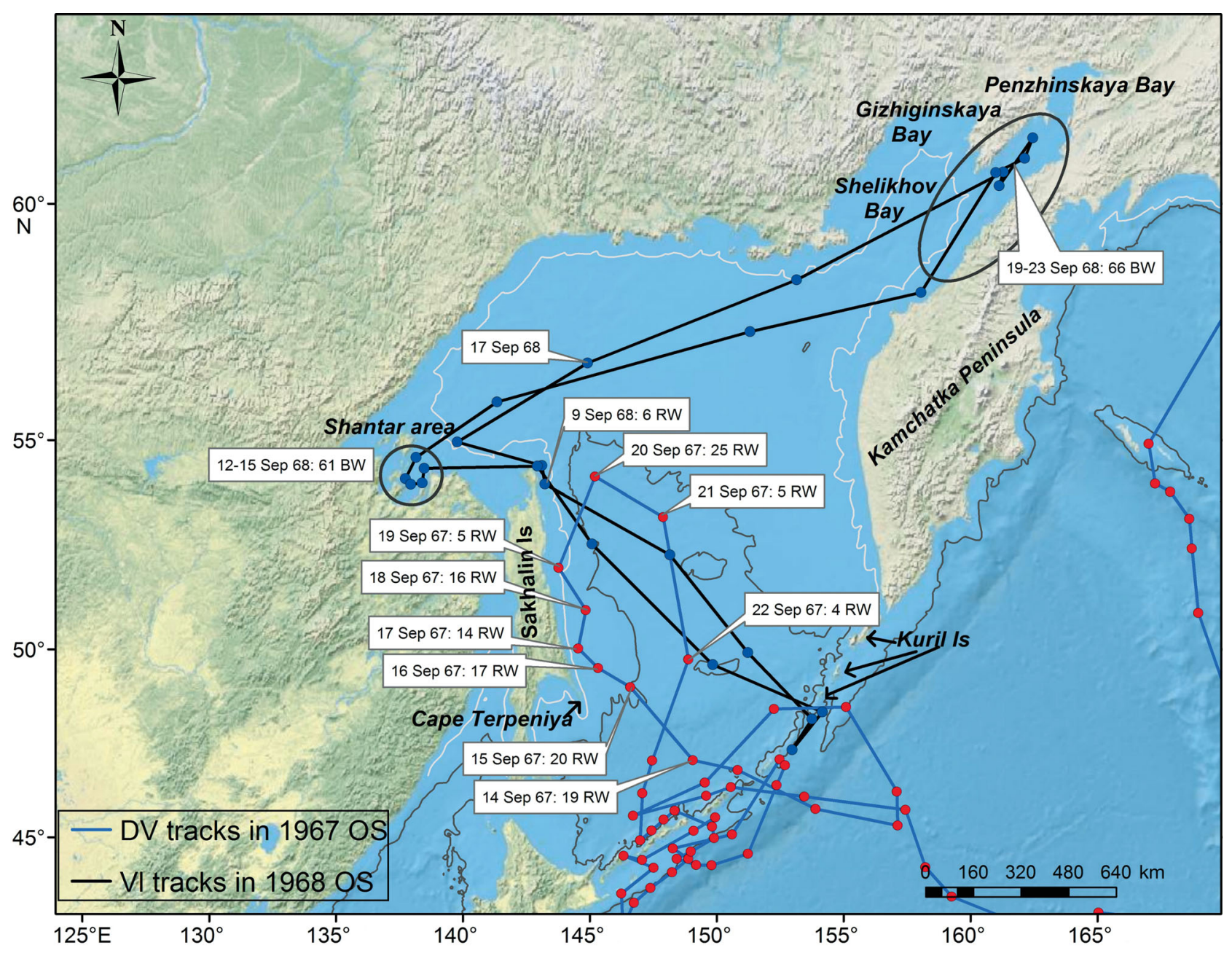

Fig. 2. Balaena mysticetus and Eubalaena japonica. Tracks of the 'Vladivostok' (Vl) whaling fleet in 1968 and the 'Dalniy Vostok' (DV) fleet in 1967, together with areas of catches of bowhead (BW) and right whales (RW) in the Okhotsk Sea. For both years, only noon positions of the factory ship and the corresponding daily catches are given; no individual catch positions are available

There is a possibility that a few more right whales were killed in the OS in other years, but there is no additional information available. Accordingly, our best estimate of the total illegal catch of right whales in the OS in 1967 and 1968 is 132 animals.

\section{Biological data}

The 'Sovetskaya Rossiya' scientific report for 1963 (Ivashin et al. 1963) includes summaries of data on length and attainment of sexual maturity in many of the 122 right whales caught by the fleet that summer (primarily in June) in the GOA. As is typical of many Russian/Soviet papers, this report is characterized by minor but careless errors of simple arithmetic, or con- tradictions between tables and text regarding small details. Where such contradictions occur, we used the data in the tables. These data are summarized in our Tables 4 \& 5, together with data from an additional 22 right whales caught by the same fleet in 1964. An overview is given below.

In 1963, right whales were caught on 5 to 7 June (4 to 6 whales $\mathrm{d}^{-1}$ ), and single animals on $18,19,22$, 23 , and 25 June; however, the majority of whales were taken from 9 to 17 June, when on some days up to 30 whales were killed. During the whole period in 1963, a predominance of males $(n=82,73.2 \%)$ was observed.

Lengths in the report are given by half-meter bins (reproduced here in Table 5); no individual length data are available. The lengths of males in the 1963 
Table 5. Eubalaena japonica. Length (in $0.5 \mathrm{~m}$ bins) and sex of right whales killed by the whaling fleet 'Sovetskaya Rossiya' in the 1963 to 1964 season. F: female; M: male

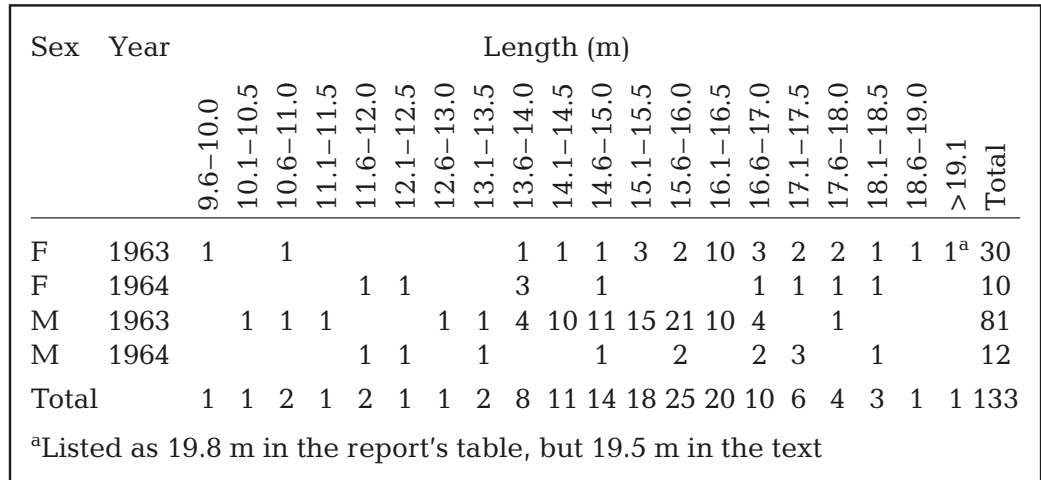

Table 6. Eubalaena japonica. Length distribution and maturational status of right whales from 1963 and 1964 catches. Additional maturity data from other published sources (Omura 1958, Klumov 1962, Omura et al. 1969) are shown in italics. Mat: mature; Imm: immature

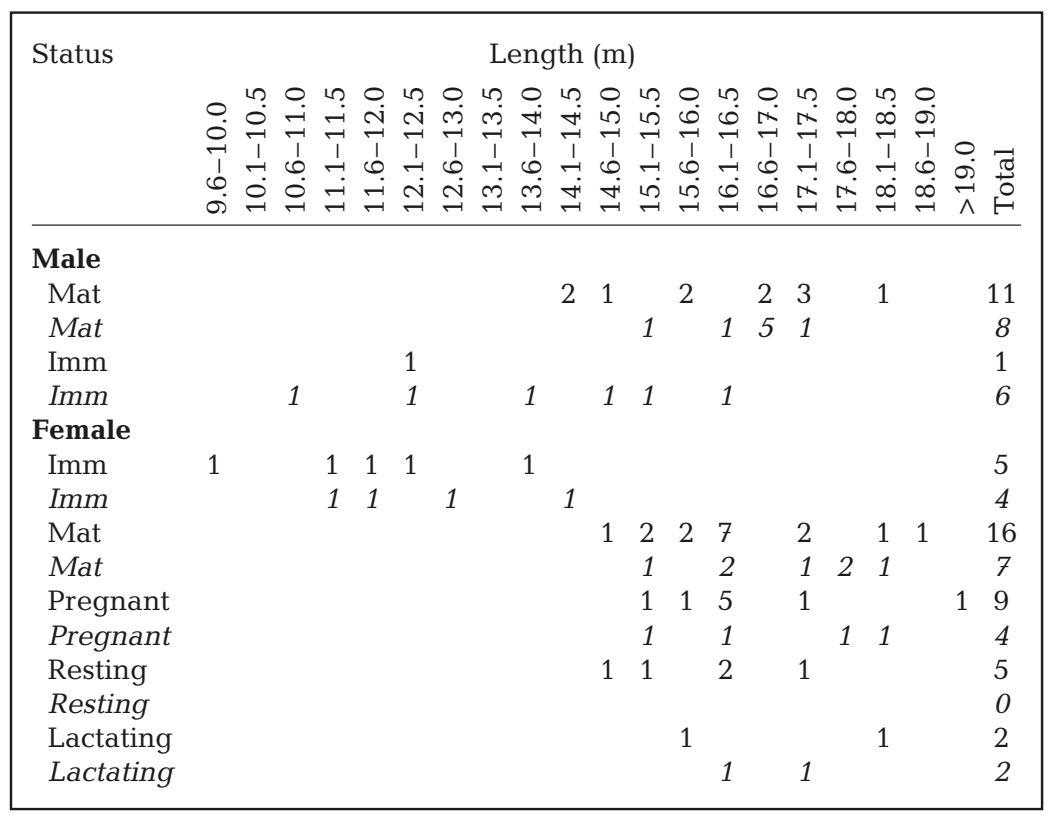

Table 6 gives data on lengths and maturational status of male and female right whales caught in 1963 and 1964; it also includes data from other studies of North Pacific right whales for comparison.

Out of the 82 males caught in 1963, 45 were examined in detail. Only 1 whale $(12.5 \mathrm{~m})$ was sexually immature. Sexual maturity in males was observed starting at a body length of $14.5 \mathrm{~m}$ (2 animals were mature at this length); however, because only 1 male (of $12.5 \mathrm{~m}$ ) of less than this length was examined, $14.5 \mathrm{~m}$ may be an overestimate of the minimum length at maturity.

Out of the 30 females in the 1963 catch, 21 were studied, and of these only 3 were immature $(9.7,11.3$, and $14.0 \mathrm{~m}$ length). Among the 18 mature females, the majority were pregnant ( $\mathrm{n}=10,55.6 \%$ ), while others were lactating $(\mathrm{n}=2,11.1 \%)$ or resting $(\mathrm{n}=6$, $32.2 \%$ ). The reported length range of pregnant females was from 15.4 to $18.4 \mathrm{~m}$, with half in the range 16.1$16.5 \mathrm{~m}(\mathrm{n}=5,50 \%)$; however, a $19.8 \mathrm{~m}$ female is reported in the text as being pregnant (with evidence that this was her fifth pregnancy), but for some reason is not included in the reported length range. Lactating females had lengths ranging from 15.8 to $18.4 \mathrm{~m}$.

Based on observations of pregnancy in a $15.4 \mathrm{~m}$ female and maturity in a $15.3 \mathrm{~m}$ female, the report from the 'Sovetskaya Rossiya' whaling fleet suggested that, by about $15.5 \mathrm{~m}$, right whales have attained sexual maturity

catch varied from $10.1-10.5 \mathrm{~m}$ to $17.5-18.0 \mathrm{~m}$. The smallest female was reported as being $9.7 \mathrm{~m}$, and the largest $19.5 \mathrm{~m}$ (this is the value given in the table; in the text it is reported as $19.8 \mathrm{~m}$ ). Overall, $68 \%$ of the total catch (76 of 112 whales, consisting of 25 of 30 females and 51 of 82 males) were animals longer than $15 \mathrm{~m}$. One calf (a female) was recorded, but its reported length of $9.7 \mathrm{~m}$ is not consistent with this being an animal in its natal year. Taking mid-point values for each length bin (e.g. $14.3 \mathrm{~m}$ as the value for the 14.1-14.5 $\mathrm{m}$ bin), the overall mean \pm SD for all recorded lengths was 15.5 $\pm 1.65 \mathrm{~m}(\mathrm{n}=133)$.
(Ivashin et al. 1963); however, this is obviously too small a sample size from which to draw any definitive conclusions.

Nine embryos were found, of which 2 were male $(110$ and $133 \mathrm{~cm})$, and 7 female $(97-232 \mathrm{~cm})$. The majority of embryos $(n=7)$ were in the length range 110 to $140 \mathrm{~cm}_{\text {; }}$ these fall within the range reported from the Southern Hemisphere for Eubalaena australis (Best 1994) as well as from elsewhere in the North Pacific (Klumov 1962, Omura et al. 1969). There are not enough data from the North Pacific to draw conclusions regarding gestation period and embryo growth. 
The right whale catches in 1964 were much smaller. Unlike in 1963 (when the catch consisted primarily of males), the reported sex ratio was almost equal (12 males and 10 females). Of 11 examined whales, only $2(18 \%)$ were immature (females of 12.52 and $12.02 \mathrm{~m})$, while the majority of whales $(9$, or $82 \%$ ) were mature. Out of 11 animals for which biological data were not collected, 2 males with a body length below $12.5 \mathrm{~m}$ and 3 females with a body length of between 13.6 and $14.0 \mathrm{~m}$ could also be considered immature based upon the data from the previous year.

The right whales killed in the OS (i.e. 126 whales taken primarily off the eastern coast of Sakhalin Island in 1967) were mostly large animals (Latishev et al. 1968). As was also the case in the 1963 GOA catches, a predominance of males was observed (82 males versus 44 females). The range of body lengths was 10.0 to $18.5 \mathrm{~m}$ for females and 11.4 to $17.7 \mathrm{~m}$ for males. The average length was reported as $15.47 \mathrm{~m}$ (females) and $15.56 \mathrm{~m}$ (males). The majority of both sexes were mature, although the figure was higher for females $(78 \%)$ than for males $(57 \%)$; the report notes that there was no selection during the hunt and that all whales seen were pursued and killed (Latishev et al. 1968). No details of individual measurements or embryos are given.

It is apparent from the table of whale lengths that full biological data were not collected for a number of smaller animals; this is very likely because the biologists concerned assumed from their lengths that these whales were immature and, unlike reproductively mature animals, were not a priority for examination. Nonetheless, even taking these animals into account it is clear that the catch consisted primarily of larger, mature whales.

\section{Bowhead whale catches}

\section{Okhotsk Sea}

Prior to this study, information on bowhead whale catches in the OS came from Doroshenko (2000a). He provided a single catch total of 133 bowhead whales taken in 1968 in the OS, as well as an anecdotal report regarding dead whales observed in 1967 (see below). Doroshenko reported that all the bowheads were taken in a single location, in the Shantar Islands; however, as detailed below we know from examination of the original whaling reports that this was not the case. Before summarizing details of bowhead whale catches, it is important to note the as- sumption of this paper with regard to species identity. The Russian term 'right whale' (гладкий кит, gladkiy kit) describes both North Pacific right whales (японский кит, Japonskiy kit) and bowhead whales (гренландский кит, Greenlandskiy kit), thus creating some confusion with regard to catches of these 2 species in areas where their distribution is known or thought to overlap. The Soviet reports, on which the following catch information is based, use this generic term, which essentially means 'balaenid whale.' For catches in some areas, notably the Shantar Islands (see Fig. 2), there is no doubt that the animals concerned were bowheads, because this area is known to be almost exclusively a habitat of this species, and has been since at least the 19th century (Ivashchenko \& Clapham 2010).

The situation with Shelikhov Bay in the northeastern OS (the other main area of catch concentration) is more equivocal; this appears to be primarily a bowhead whale habitat, but North Pacific right whales have occasionally been reported there (see discussion in Ivashchenko \& Clapham 2010). Additional catches of North Pacific right and bowhead whales in the area nearby and at the same time are reported by Reeves et al. (2008). This review makes the assumption that the Soviet catches from Shelikhov Bay were all bowheads. This is based in part upon historical distribution showing bowheads as the primary species found there (Townsend 1935), as well as on an observation made by a Soviet research vessel in 1967. That survey found a large group of 'right whales' (again, the Russian generic term for balaenids) in the lower part of Penzhinskaya Bay, seen at dusk on 4 August; the survey recorded them as bowheads, but because of fading light the species was not confirmed (Rovnin 1969, Kuzmin \& Berzin 1974). Despite the preponderance of evidence, we cannot exclude the possibility that some of the whales killed in Shelikhov Bay were right whales, and our results are reported with that caveat.

A small aggregation of bowhead whales in the Shantar Islands was found during a scientific cruise in June 1967 (Kuzmin \& Berzin 1974); later in the same season, the 'Aleut' whaling fleet went into this area to hunt (Doroshenko 2000a). Data for the bowhead catches in 1967 are not available (and probably no longer exist); the only known information from this year consists of an observation of floating intestines of 'at least 18 bowheads' observed in September (G. A. Fedoseev pers. comm. to N. V. Doroshenko).

For the 1968 season, Doroshenko (2000a) listed a total of 133 bowhead whales killed in the Shantar 
area. However, a report of the whaling inspectors for the 'Vladivostok' whaling fleet (Reznichenko \& Selyavko 1968) describes in considerable detail catches made in September 1968 in the OS, and it is clear that these were not confined to the Shantars. The whaling fleet's track is shown in Fig. 2. The fleet first moved from the Kuril Islands into the northern OS. On 11 September, 6 'right whales' (likely Eubalaena japonica, see above) were killed off northern Sakhalin.

After this, the fleet moved to the Shantar region, and in just $4 \mathrm{~d}$ (12-15 September) killed 61 bowhead whales, primarily in Academia Bay; the majority consisted of what was described as small animals. The fleet then left this area and, after catching fin whales Balaenoptera physalus in the middle of the OS, moved northeast into Shelikhov Bay. There they first took some single bowheads, and later found an aggregation to the northeast, in Penzhinskaya Bay. During $5 \mathrm{~d}$ of working in this latter area, 66 bowhead whales were killed. In total, the 'Vladivostok' fleet killed 133 balaenid whales ( 76 males and 57 females; Reznichenko \& Selyavko 1968), although as noted above, at least 6 of them were probably North Pacific right whales. Our best estimate for the number of bowhead whales killed in the OS is 145 (a minimum of 18 in 1967 and 127 in 1968).

\section{Biological data}

In a table of length distribution presented at the end of the inspectors' report (Reznichenko \& Selyavko 1968), the reported range for 'right whales' (again, we assume mainly bowheads) was from 9.0 to $16.5 \mathrm{~m}$. A large portion of the catch (79 out of 133 whales) was in the range 11.5 to $13.5 \mathrm{~m}$, and in all, 90 whales had a body length below $13.5 \mathrm{~m}$. Analysis of data collected from the Alaskan Eskimo native hunt, as well as photogrammetry work, shows that most female bowheads become sexually mature at about 13.0 to $13.5 \mathrm{~m}$ in length; little information is available with regard to the length of maturity in males, but it is likely that most male bowheads become mature by 12 to $13 \mathrm{~m}$ (Koski et al. 1993). Based on these length parameters, 34 of 57 females $(59.6 \%)$ in the 1968 Soviet catch, and 23 of 76 males (30.3\%) would have been immature. As noted above, the whales taken at Shantar were described as 'small,' which is consistent with the general belief that this region primarily hosts younger whales, in contrast to the larger adults found in Shelikhov Bay (Ivashchenko \& Clapham 2010).

\section{DISCUSSION}

\section{North Pacific right whales}

The new details regarding sightings and catches of North Pacific right whales in the eastern and western North Pacific adds to our understanding of these 2 populations and their history. The catches by 'Sovetskaya Rossiya' in the GOA in 1963 significantly increase the total removal of right whales from the eastern stock; if our assumptions about possible duplication are correct (see above), our best estimate for the number of right whales taken in the eastern North Pacific between 1962 and 1968 is 529 compared to the previously reported number of 372 whales (Doroshenko 2000a).

The fact that these catches were larger than previously believed, in combination with the removal of a large number of mature animals, further explains the current precarious state and lack of recovery of this population, which was probably driven to extremely low numbers with only a few surviving mature whales. There is also some uncertainty about possible additional catches by the 'Aleut' factory fleet. Nonetheless, irrespective of these uncertainties, it is very likely that these illegal catches reduced the bulk of the eastern population to such low numbers that, 40 yr later, this stock remains extremely small, and today it is considered Critically Endangered (Wade et al. 2011).

Biological data on North Pacific right whales are relatively rare, largely because the species was protected in 1935, and few specimens were officially available for examination. Existing data come entirely from scientific research catches of 13 whales made by Japan at various times over the period 1956 to 1968 (Omura 1958, Omura et al. 1969), and from another 10 whales killed under scientific permit by the USSR in the Kuril Islands in 1955 (Klumov 1962). Biological information collected in 1963 and 1964 presents valuable new data for this species. It also gives a new record for right whale body length in the North Pacific as $19.5 \mathrm{~m}$ (or $19.8 \mathrm{~m}$ as given in the scientific report text), compared to the previous maximum recorded length of $18.3 \mathrm{~m}$ (Klumov 1962). The question of which animal represents the record length is complicated by the noted discrepancy between text and table of 19.5 versus $19.8 \mathrm{~m}$, as well as by the fact that the scientific report for the 'Sovetskaya Rossiya' fleet for 1965 (Latishev et al. 1965) states that a right whale with a length of $19.7 \mathrm{~m}$ was 1 of 7 animals taken that year in the GOA. 
Overall, the body length at maturity based on the data from illegal catches for males could be placed roughly in the range between 12.5 and $14.5 \mathrm{~m}(12$ whales measured; Table 6), because only 1 male $<14.0 \mathrm{~m}$ in length was examined. With additional data from Japanese and Soviet scientific catches (14 whales), mature and immature males overlap in the range 14.1 to $15.5 \mathrm{~m}$ (we exclude as anomalous 1 male from Omura et al. 1969 with a body length of $16.4 \mathrm{~m}$ and a testis weight of only $9 \mathrm{~kg}$ ). This supports the conclusion of Soviet and Japanese scientists that sexual maturity in male right whales begins at a body length between 14.5 and $15.5 \mathrm{~m}$ (Klumov 1962, Ivashin et al. 1963, Omura et al. 1969). In the case of females of this species, the combined data (21 illegal whales and 11 from the literature) show that a length of $14.5 \mathrm{~m}$ is a line that broadly separates mature and immature animals. Although the amount of data is still very limited, and it is premature to draw any final conclusions based on only 32 measurements, the length at which females reach sexual maturity seems to be between about 14.1 and $15.0 \mathrm{~m}$. That is in the agreement with the length at maturity proposed by Soviet scientists as 14.1 to $14.5 \mathrm{~m}$ (Klumov 1962, Ivashin et al. 1963), but lower than that suggested by Omura et al. (1969) as 15.0 to $16.0 \mathrm{~m}$.

The distribution of the GOA catches and sightings is very similar to the historical whaling catches of right whales as plotted by Townsend (1935), suggesting that the distribution of right whales in the GOA has not changed since the 19th century. Furthermore, the comparatively recent Soviet sightings and catches suggest that the offshore GOA contains habitats that likely remain important to right whales today.

The location of the Soviet right whale catches in the BS is known only approximately in most cases, with the majority shown by Doroshenko (2000a) as a general area to the west of Bristol Bay. Recent surveys by the Alaska Fisheries Science Center's National Marine Mammal Laboratory have found small numbers of right whales in this region (Clapham et al. 2012); the middle shelf domain of the southeastern BS is clearly important as a feeding area, and right whale calls have been heard there on passive acoustic recorders almost yearround. However, survey effort in the BS, and in the adjacent Aleutian Islands, currently remains low or non-existent.

In the OS, the Soviet catches were distributed over a large area along the eastern coast of Sakhalin Island, and this range encompasses some of the same areas where right whales were observed during
Japanese sighting surveys conducted in 1989 to 2003 (Miyashita 1997, Miyashita \& Doroshenko 1990, Miyashita et al. 2001, Miyashita 2004). This suggests that these areas remain important to western right whales.

Future research should concentrate on the areas identified in this paper. While the BS has been the focus of some survey effort in recent years (Clapham et al. 2012), further work there awaits funding. Elsewhere, surveys are urgently needed to assess whether a viable population of right whales exists in the GOA, which has received very little dedicated survey effort since the Soviet catches of the 1960s. Sighting surveys of a part of the GOA in 2009 (Rone et al. 2009) and in 2011 (K. Matsuoka pers. comm.) found no right whales; however, such surveys with low coverage of the area would inevitably have a low probability of finding what may be a small number of whales, especially if they are concentrated in a limited portion of this vast area of ocean.

\section{Bowhead whales}

The main source of knowledge regarding the current seasonal distribution of bowhead whales in the OS comes from a number of ship-based and aerial surveys conducted by Soviet and Russian scientists from 1967 to 2001 (Berzin et al. 1986, Doroshenko 1996, Ivannikov \& Doroshenko 2003). Two main areas, the Shantars and Shelikhov Bay, yielded the majority of sightings, but in Shelikhov Bay, bowhead whales were observed only during the months of spring to early summer. There was some survey effort in Shelikhov Bay in September and October, but the effort appears to have been low, and there is no detail regarding the geographic coverage involved (Ivashchenko \& Clapham 2010).

Doroshenko (1996) proposed that bowhead whales occupy Shelikhov Bay only in spring and leave by the end of May, moving toward the western side of the OS to the Shantar area. However, this was based upon relatively low survey effort from both areas, and did not take into account historical whaling data, nor the idea that the population is at least partly segregated by size, as noted above. The whaling report from the 'Vladivostok' fleet's 1968 season is the only modern record showing the presence of bowhead whales in Shelikhov Bay in September, although as noted, Russian survey effort in autumn has been very limited. Assuming that the species determination for these catches is indeed correct, this information (as well as the observation of probable bowheads there 
in August 1967) extends our knowledge of the period when bowhead whales use Shelikhov Bay to include the summer and early fall. The belief that bowheads utilize the Shelikhov Bay region during these seasons is supported by records compiled from 19th century American whaling ships by Townsend (1935), which show a significant number of catches through all months of summer as well as in September (see Fig. 2 in Ivashchenko \& Clapham 2010).

That the more recent Soviet and Russian studies failed to systematically survey this area in summer and fall (Ivashchenko \& Clapham 2010) is likely due in part to the fact that the information contained in the formerly secret whaling industry reports was unavailable to the scientists planning these surveys, thus resulting in incomplete and temporally limited coverage of the area. It is also possible that the Soviet catches so depleted the population in Shelikhov Bay that few remained to be observed in later surveys.

Overall, we believe that the minimum Soviet catch of bowhead whales in the OS during the period of illegal whaling was 145 animals, taken in 1967 (18) and 1968 (127). However, as noted above, we cannot with certainty exclude the possibility that some of the whales killed in the Shelikhov Bay region were North Pacific right whales, so this figure must remain tentative; unfortunately, it is unlikely that any new information will become available to solidify this conclusion.

\section{CONCLUSIONS}

The material examined during this study gives new information on the size, timing, and distribution of Soviet illegal catches of both bowhead and North Pacific right whales in the North Pacific and OS, and also provides some rare biological data regarding lengths and sexual maturity.

The question of the degree to which the occurrence and distribution of bowheads overlap with that of North Pacific right whales in the OS is worth pursuing. Although right whales and bowheads elsewhere in the Northern Hemisphere (i.e. in the subarctic North Pacific and North Atlantic) are today rarely found in the same habitats at the same times of year, this may be in part a function of the current low abundance of right whales, which were reduced to small populations in all regions, with corresponding reductions in range. Further research using 19th century whaling logbooks and journals may shed light on this issue as it relates to the OS.
Whether catches of bowheads and right whales were made in other years is unknown, but not unlikely. Both the 'Vladivostok' and 'Dalniy Vostok' fleets regularly worked in the OS as fishing factory vessels, and it is known (from both fleet reports and personal communications from former whalers) that whaling catchers would join these fleets prior to the official start of the whaling season.

The uncertainty about total catches notwithstanding, it is clear that the populations of both bowhead and North Pacific right whales in the OS were significantly reduced by the illegal Soviet catches, and surveys to assess their status today are clearly needed, notably in light of expanding oil and gas development in the northern OS. In recent years, research on bowheads has been conducted only in the Shantar area (Brownell et al. 1997, Maclean 2002, LeDuc et al. 2005). We strongly recommend that future surveys focus on Shelikhov Bay; although this was clearly an important habitat, and likely remains so, it has been largely neglected in marine mammal surveys to date.

Current evidence strongly suggests that right whales are now perilously close to extinction in the eastern North Pacific (Wade et al. 2011). Incorporation of the new catch data into a model to reconstruct the trend and historic size of the population might be feasible. At a more basic level, surveys are urgently needed to better assess the status of this population. This is particularly important for the GOA, which has received little or no survey effort in the years following the Soviet catches, which likely removed the bulk of what may have been a small but slowly recovering population. Aerial or shipboard surveys, together with extensive passive acoustic monitoring, would go a long way towards establishing the status of what may well be the world's most endangered population of large whales.

Acknowledgements. We thank N. V. Doroshenko for considerable assistance in clarifying details of Soviet whaling catches, and R. Brownell for frequent input and advice. Funding for this work through a Mia J. Tegner award to Y.V.I. by the Marine Conservation Institute is gratefully acknowledged. Opinions expressed by the authors do not reflect those of the National Marine Fisheries Service. Reference to trade names does not indicate endorsement by the National Marine Fisheries Service.

\section{LITERATURE CITED}

Anonymous (1962a) Promisloviy otchet kitobolnoy flotilii Sovetskaya Rossiya za promisel 1961-1962 goda [Whaling report of the whaling fleet Sovetskaya Rossiya for the 1961-1962 season]. Upravlenie Proizvodstvennikh Flotiliy 'Dal'moreproduct', Vladivostok 
Anonymous (1962b) Promisloviy otchet kitoboynoy flotilii Vladivostok za 1962 god [Whaling production report of the whaling fleet Vladivostok for the 1962 season]. Upravlenie Kitoboinikh Flotiliy, Vladivostok

Anonymous (1963a) Promisloviy otchet kitoboynoy flotilii Sovetskaya Rossiya za promisel 1963 goda [Whaling report of the whaling fleet Sovetskaya Rossiya for the 1963 season]. Vladivostok

Anonymous (1963b) Promisloviy otchet flotiliy Aleut, Vladivostok, Dalniy Vostok za promisel 1963 goda [Whaling production report of the whaling fleets Aleut, Vladivostok, Dalniy Vostok during the 1963 season]. Upravlenie Proizvodstvennikh Flotiliy 'Dal'moreprodukt', Vladivostok

Berzin AA, Rovnin AA (1966) The distribution and migrations of whales in the northeastern part of the Pacific, Chukchee and Bering Seas. Izvest TINRO 58:179-207

Berzin AA, Vladimirov VL, Doroshenko NV (1986) Cetaceans in the coastal waters of the Okhotsk Sea: results from aerial surveys. Rep Int Whal Comm 37:395-398

Best PB (1994) Seasonality of reproduction and the length of gestation in southern right whales Eubalaena australis. J Zool 232:175-189

Best PB, Banister, JL, Brownell RL Jr, Donovan GP (eds) (2001) Right whales: worldwide status. J Cetacean Res Manag (Spec Issue 2)

Bockstoce JR, Burns JJ (1993) Commercial whaling in the North Pacific sector. In: Burns JJ, Montague JJ, Cowles CJ (eds) The bowhead whale. Spec Publ 2, Soc Mar Mammal. Allen Press, Lawrence, KS, p 563-577

Brownell RL Jr, Burdin AM, Blokhin SA, Berzin AA (1997) Observations on bowhead whales (Balaena mysticetus) in the Shantar Archipelago, western Okhotsk Sea. IBI Rep 7:1-7

Brownell RL Jr, Clapham PJ, Miyashita T, Kasuya T (2001) Conservation status of North Pacific right whales. J Cetacean Res Manag 2:269-286 (SI)

Burns JJ, Montague JJ, Cowles CJ (eds) (1993) The bowhead whale. Spec Publ 2, Soc Mar Mammal. Allen Press, Lawrence, KS

Clapham PJ, Ivashchenko YV (2009) A whale of a deception. Mar Fish Rev 71:44-52

Clapham PJ, Young SB, Brownell RL Jr (1999) Baleen whales: conservation issues and the status of the most endangered populations. Mammal Rev 29:35-60

Clapham PJ, Kennedy AS, Rone BK, Zerbini AN, Crance JL, Berchok CL (2012) North Pacific right whales in the southeastern Bering Sea. Final report to the Bureau of Ocean Energy Management under Inter-Agency Agreement number M07RG13267. National Marine Mammal Laboratory, Seattle, WA

Doroshenko NV (1996) Grenlandskie kiti Okhotskogo morya [Bowhead whales of the Sea of Okhotsk]. Ecological investigation of the Far Eastern marine mammals. Izvest TINRO 121:14-25

Doroshenko NV (2000a) Soviet whaling for blue, gray, bowhead and right whales in the North Pacific Ocean, 1961-1979. In: Yablokov AV, Zemskiy VA (eds) Soviet whaling data (1949-1979). Center for Russian Environmental Policy, Moscow, p 96-103

Doroshenko NV (2000b) Soviet catches of humpback whales (Megaptera novaeangliae) in the North Pacific. In: Yablokov AV, Zemskiy VA (eds) Soviet whaling data (1949-1979). Center for Russian Environmental Policy, Moscow, p 48-95
Doroshenko NV, Rovnin AA, Davidova GD, Tarasevich MN (1965) Biologicheskie obosnovaniya razvitiya i ratsional'nogo vedeniya promisla morskikh mlekopitayushchikh [Biological justification of the development and rational way of marine mammal hunting] Vol 1. VNIRO, Moscow

Ivannikov DV, Doroshenko NV (2003) Results of the cetacean ship-based survey in the Sea of Okhotsk in September-October 2001. Paper SC/55/O3. International Whaling Commission, Cambridge

Ivashchenko YV, Clapham PJ (2010) Bowhead whales Balaena mysticetus in the Okhotsk Sea. Mammal Rev 40: 65-89

Ivashchenko YV, Clapham PJ, Brownell RL Jr (eds) (2008) The truth about Soviet whaling: a memoir, by A. A. Berzin [translated by Y. V. Ivashchenko]. Mar Fish Rev 70:1-59

Ivashchenko YV, Clapham PJ, Brownell RL Jr (2011) Soviet illegal whaling: the devil and the details. Mar Fish Rev 73:1-19

Ivashin MV, Smishlyaev MI, Rakov AV, Trapeznikova LV, Gushchina VN, Zavernin YP (1963) Predvaritel'niy otchet o rabote nauchnoy gruppi k/f Sovetskaya Rossiya za promisel 1962-63 goda [Preliminary report of a scientific group on the whaling fleet Sovetskaya Rossiya during the 1962-63 season]. TINRO, Vladivostok

Klumov SK (1962) Gladkie (yaponskie) kity Tikhogo okeana [Right whales in the Pacific Ocean]. Trudy Inst Okeanol 58:202-297

Koski WR, Davis RA, Miller GW, Withrow DE (1993) Reproduction. In: Burns JJ, Montague JJ, Cowles CJ (eds) The bowhead whale. Spec Publ 2, Soc Mar Mammal. Allen Press, Lawrence, KS, p 239-274

Kugler RC (1984) Historical survey of foreign whaling: North America. In: Arctic whaling: Proc Int Symp. University of Groningen, p 149-157

Kulikov VF, Borisov VI, Mokrenok GG, Korneev HA, Kirienko VD (1964) Biologicheskie issledovaniya kitov Antarktiki na AKF Sovetskaya Rossiya v period 3-go promislovogo reysa (1963-1964) [Biological studies of whales in the Antarctic on board AWF Sovetskaya Rossiya during the third whaling season 1963-64]. Upravlenie Kitoboinikh Flotiliy TINRO, Vladivostok

Kuzmin AA, Berzin AA (1974) Distribution and current abundance of right and gray whales in the Okhotsk, Bering and Chukchi seas. Report of the scientific cruise Tamago in 1974. TINRO, Vladivostok

Latishev VM (1962) Kratkiy otchet o razvedke kitov u tikhokeanskogopoberezh'ya Savernoy Ameriki, severnoy chasti zaliva Alyaska, Beringovom i chukotskom moryakh, proizvedennoy na STR-4454 s maya po oktyabr' 1962 goda [Brief report of a scout survey of whales off the Pacific coast of North America, northern part of Gulf of Alaska, Bering and Chukchi Seas, conducted by STR-4454 from May to October 1962]. TINRO, Vladivostok

Latishev VM, Mokrenok GG, Karneev HA (1965) Otchet o rebote nauchnoy gruppi kitoboynov flotilii Sovetskaya Rossiya za promisel 1964-65 goda [Report of the results for the scientific group of the whaling fleet Sovetskaya Rossiya during the 1964-65 season]. TINRO, Vladivostok

Latishev VM, Doroshenko NV, Erdakov LN, Beinger GM, Bardin FM, Latisheva IM (1968) Sostoyanie zapasov kitov v severnoy chasti Tikhogo okeana [Conditions of whale resources in the northern part of the Pacific Ocean]. TINRO, Vladivostok 
LeDuc RG, Dizon AE, Burdin AM, Blokhin SA, George JC, Brownell RL Jr (2005) Genetic analyses (mtDNA and microsatellites) of Okhotsk and Bering/Chukchi/Beaufort Seas populations of bowhead whales. J Cetacean Res Manag 7:107-111

Maclean SA (2002) Occurrence, behavior and genetic diversity of bowhead whales in the western Sea of Okhotsk, Russia. MS thesis, Texas A\&M University, College Station, TX

Mitchell E (1977) Initial population size of bowhead whale (Balaena mysticetus) stocks: cumulative catch estimates. Paper SC/29/Doc 33. International Whaling Commission, Cambridge

Miyashita T (1997) Distribution of whales in the Sea of Okhotsk, results of the recent sighting cruises. IBI Rep 7: 21-38

Miyashita T (2004) Cruise report on the minke whale sighting survey in the Sea of Okhotsk in 2003. SC/56/RMP1 SC/53/RMP5. International Whaling Commission, Cambridge

Miyashita T, Doroshenko NV (1990) Report of the whale sightings survey in the Okhotsk Sea August 1989. SC/42/O18. International Whaling Commission, Cambridge

Miyashita T, Kato H (1998) Recent data on the status of right whales in the NW Pacific Ocean. Paper SC/M98/RW11 presented to the IWC Special Meeting of the Scientific Committee towards a Comprehensive Assessment of Right Whales Worldwide, 16-25 March, Cape Town, South Africa. International Whaling Commission, Cambridge

Miyashita T, Nishiwaki S, Vladimirov VA, Doroshenko NV (2001) Cruise report on the minke whale sighting survey in the Sea of Okhotsk, 2000. SC/53/RMP5. International Whaling Commission, Cambridge

Omura H (1958) North Pacific right whale. Sci Rep Whales Res Inst Tokyo 13:1-52

Omura H, Ohsumi S, Nemoto T, Nasu K, Kasuya T (1969) Black right whales in the North Pacific. Sci Rep Whales Res Inst Tokyo 21:1-78

Petukhov PP (1964) Otchet o nauchno-poiskovom reise STR Birokan po izucheniyu kitov v vostochnoy chasti Tikhogo okeana, prodolzhavsheesya s decabrya 1963g. po iyun' 1964g [Report of the scientific-scout survey of STR Birokan to study whales in the eastern part of the Pacific Ocean, from December 1963 through June 1964]. TINRO, Vladivostok

Raskatov EA, Latishev VM (1967) Otchet gosudarstvennikh inspectorov po kitoboynomu promislu za promisloviy sezon 1967 goda na kitoboynoy flotilii Dalniy Vostok [Report of State whaling inspectors during the 1967 season of the whaling fleet Dalniy Vostok]. TINRO, Vladivostok

Reeves RR, Smith TD, Josephson EA (2008) Observations of western gray whales by ship-based whalers in the 19th century. J Cetacean Res Manag 10:247-256

Editorial responsibility: Brendan Godley,

University of Exeter, Cornwall Campus, UK
Reilly SB, Bannister JL, Best PB, Brown M and others (2008) Balaena mysticetus (Okhotsk Sea subpopulation). In: IUCN Red List of Threatened Species. Version 2011.1. Available at www.iucnredlist.org

Reznichenko V, Selyavko O (1968) Otchet o rabote gosudarstvennoy inspectsii po kitoboinomu promislu na kitoboynoy flotilii Vladivostok za promisel 1968 goda [Report of the whaling State inspection of the whaling fleet Vladivostok during the 1968 season]. Upravlenie proizvodstvennikh flotiliy 'Dal'moreproduct,' Vladivostok

Rone BK, Douglas AB, Clapham P, Martinez A, Morse LJ, Zerbini AN, Calambokidis J (2009) Final report for the Gulf of Alaska Line Transect Survey (GOALS) in the Navy training exercise area. National Marine Mammal Laboratory, Seattle, WA

Rovnin AA (1969) Raspredelenie kitov v severnoy i tsentral'noy chasti Tikhogo okeana [Whale distribution in the northern and central parts of the North Pacific]. PhD dissertation, TINRO, Vladivostok

Rugh D, Demaster D, Rooney A, Breiwick J, Shelden K, Moore S (2003) A review of bowhead whale (Balaena mysticetus) stock identity. J Cetacean Res Manag 5: $267-279$

Scarff JE (1991) Historic distribution and abundance of the right whale (Eubalaena glacialis) in the North Pacific, Bering Sea, Sea of Okhotsk and Sea of Japan from Maury Whale Charts. Rep Int Whal Comm 41:467-489

Scarff JE (2001) Preliminary estimates of whaling-induced mortality in the 19th century North Pacific right whale (Eubalaena japonicus) fishery, adjusting for struck-butlost whales and non-American whaling. J Cetacean Res Manag 2(Spec Issue):261-268

Townsend $\mathrm{CH}$ (1935) The distribution of certain whales as shown by logbook records of American whaleships. Zoologica (NY) 19:1-50

Troinin VI (1962a) Informatsionniy otchet o razvedke kitov v severo-vostochnoy chasti Tikhogo okeana v 1959-61 [Information report on a scout survey of whales in the north-eastern part of the North Pacific in 1959-61]. TINRO, Vladivostok

Troinin VI (1962b) Kratkiy otchet o razvedke kitov v severovostochnoy chasti Tikhogo okeana, Beringovom i Chukotskom moryakh, proizvedennoy na k/s Buran v aprele - avguste 1962 goda [Brief report of a scout survey of whales in the north-eastern part of the Pacific Ocean, Bering and Chukchi Seas, conducted from the catcher Buran during April - August 1962]. TINRO, Vladivostok

> Wade PR, Kennedy A, LeDuc R, Barlow J and others (2011) The world's smallest whale population? Biol Lett 7:83-85

Woodby DA, Botkin DB (1993) Stock sizes prior to commercial whaling. In: Burns JJ, Montague JJ, Cowles CJ (eds) The bowhead whale. Spec Publ 2, Soc Mar Mammal. Allen Press, Lawrence, KS, p 387-417

Yablokov AV (1995) Preface. In: Soviet Antarctic whaling data (1947-1972). Center for Russian Environmental Policy, Moscow, p 4-6

Submitted: January 31, 2012; Accepted: June 7, 2012 Proofs received from author(s): August 15, 2012 